\title{
Pengaruh Tepung Daun Singkong (Manihot utilissima) terhadap Sensori dan Aktivitas Antioksidan Beras Analog
}

\author{
Marfu'atul Jannah ${ }^{1}$ dan Bernatal Saragih ${ }^{2}$ \\ Progam StudiTeknologi Hasil Pertanian Fakultas Pertanian Universitas Mulawarman \\ Jl. Paser Balengkong Po Box 1040 Kampus Gunung Kelua Samarinda 75119 \\ 2 Email: saragih bernatal@yahoo.com
}

\begin{abstract}
The development of new products from various flour very important to support food security. Cassava leaves made into flour can be used as food diversification with alternative food development efforts. The aim of the study was to determine the effect of adding cassava leaf flour to the sensory and antioxidant properties of analog rice. This research used a non factorial Completely Randomized Design (CRD) with five treatments, the ratio of mocaf and corn flour $(80 \mathrm{~g}$ and $20 \mathrm{~g}$ ) with a total weight of 100 $g$ of the addition of ingredients with 5 treatment of cassava leaves flour concentration of $0,2,4,6$ and $8 \mathrm{~g}$. Organoleptic data was processed using MSI (Method of Successive Interval) before being analyzed with ANOVA. The treatment showed significantly different were tested by the Least Significance Difference (LSD) at the a 5\% level. Cassava flour added significantly to the sensory and antioxidant activity. The cassava flour analogue rice has strong antioxidant activity (50-100 ppm) with IC50 value 53,424 $\mathrm{ppm}$. The best treatment is in the treatment with the addition of $2 \mathrm{~g}$ of hedonic cassava flour color, the flavor and taste is like. Quality of color, aroma, taste and texture is a rather green color, slightly scented cassava leaves, a little taste of cassava leaves, chewy.
\end{abstract}

Keywords: cassava leaves flour, analog rice, antioxidant activity

\begin{abstract}
ABSTRAK
Pengembangan produk-produk baru dari berbagai tepung untuk mendukung ketahanan pangan sangat penting dilakukan. Salah satu yang perlu dikembangkan adalah daun singkong yang dibuat menjadi tepung dapat digunakan sebagai diversifikasi makanan dengan upaya pengembangan makanan alternatif. Tujuan penelitian untuk mengetahui pengaruh penambahan tepung daun singkong terhadap sifat sensoris dan antioksidan beras analog. Penelitian ini menggunakan Rancangan Acak Lengkap (RAL) dengan lima perlakuan, perbandingan mocaf dan tepung jagung $(80 \mathrm{~g}$ dan $20 \mathrm{~g})$ dengan total berat $100 \mathrm{~g}$ bahan tambahan dengan 5 perlakuan konsentrasi tepung daun singkong 0 , 2, 4, 6 dan $8 \mathrm{~g}$. Data organoleptik diolah menggunakan MSI (Method of Successive Interval) sebelum dianalisis dengan ANOVA dan diuji lanjut dengan uji BNT(Beda Nyata Terkecil) pada taraf $5 \%$. Penambahan tepung daun singkong meningkatkan sensorik dan antioksidan. Nasi analog tepung singkong memiliki aktivitas antioksidan yang kuat (50-100 ppm) dengan nilai IC50 53,424 ppm. Perlakuan terbaik adalah dengan penambahan $2 \mathrm{~g}$ dengan warna yang agak hijau, agak beraroma tepung daun singkong, agak berasa tepung daun singkong dan agak kenyal.
\end{abstract}

Kata kunci: tepung daun singkong, beras analog, aktivitas antioksidan

\section{Pendahuluan}

Indonesia merupakan negara yang memiliki sumber daya alam yang melimpah.

Pertanian Indonesia dapat digunakan untuk memenuhi kebutuhan warga negara Indonesia seperti pemenuhan kebutuhan pangan (Christianto, 2013). Pangan di Indonesia mempunyai kedudukan yang sangat penting, terutama makanan pokok, karena menyangkut permasalahan politik, ekonomi, sosial dan budaya. Sebagian besar makanan 
Jurnal Pertanian Terpadu 6(2): 96-108 ISSN 2549-7383 (online)

http://ojs.stiperkutim.ac.id/index.php/jpt ISSN 2354-7251 (print)

pokok penduduk berasal dari serealia yang terdiri dari beras, jagung dan terigu dan terbesar sebagai makanan pokok penduduk adalah beras. Masyarakat umumnya mempunyai ketergantungan yang kuat terhadap beras sebagai sumber karbohidrat dan sebagai upaya mengurangi ketergantungan masyarakat pada beras maka perlu menggali potensi lokal yang berbasis non beras untuk memenuhi kebutuhan pangannya (Suyastiri, 2008).

Badan Pusat Statistik (BPS) Nasional (2016), mencatat konsumsi beras nasional sebesar 113,88 kg/kapita/tahun dan meningkat sebesar 114,11 kg/kapita/tahun pada tahun 2015. Beras yang tersedia belum mencukupi kebutuhan beras di Indonesia sehingga Indonesia harus mengimpor beras dari negara lain (Hartoyo, 2000). Target progam kementrian pertanian pada tahun 2012 adalah menurunnya konsumsi beras 1,5\% per tahun dengan digantikan oleh sumber karbohidrat lokal (Yuwono dan Zulfiah, 2015). Pelaksanaan program diversifikasi atau penganekaragaman pangan di Indonesia telah mempunyai dasar hukum yang kuat melalui UU Pangan No. 7 tahun 2006 tentang Pangan, PP No. 68 tahun 2002 tentang Ketahanan Pangan tentang Kebijakan Percepatan Penganekaragaman Konsumsi Pangan Berbasis Sumberdaya Lokal (Ariani, 2010).

Konsumsi beras masyarakat Indonesia yang terus mingkat, maka perlu paya dalam mengurangi ketergantungan dengan mengembangkan alternatif pangan. Alternatif pangan yang dikembangkan misalnya menyerupai beras namun tidak murni terbuat dari beras (Wijaya, 2012). Beras analog merupakan salah satu bentuk solusi yang dapat dikembangkan dalam mengatasi permasalahan ini baik dalam hal penggunaan sumber pangan baru ataupun untuk penganekaragaman pangan. Beras analog merupakan tiruan dari beras yang terbuat dari bahan-bahan seperti umbi-umbian dan serealia yang bentuk maupun komposisi gizinya mirip seperti beras. Khusus untuk komposisi gizinya, beras analog bahkan dapat melebihi apa yang dimiliki beras (Budijanto dkk., 2013).

Salah satu bentuk diversifikasi pangan dengan memanfaatkan sumber karbohidrat lokal ialah dengan membuat inovasi beras analog berbasis tepung Mocaf (Modified Cassava Flour) dan tepung jagung. Beras analog adalah beras tiruan yang terbuat dari bahan baku selain beras dan terigu salah satu tepung lokal yang dapat dimanfaatkan adalah Mocaf yang merupakan hasil dari tepung singkong yang difermentasi dengan bantuan bakteri asam laktat kata Mocaf adalah singkatan dari Modified Cassava Flour yang berarti tepung singkong yang dimodifikasi (Subagio dkk., 2008).

Daun singkong yang berwarna hijau telah dilaporkan (Alsuhendra, 2004) mengandung klorofil yang paling tinggi dibandingkan dengan tanaman daun katuk, daun pohon-pohan, daun kangkung, daun bayam, caisin, buncis, selada, daun kemangi, alangalang dan rumput gajah. Klorofil dan turunannya (yang mengikat logam) mempunyai kapasitas antioksidan dan bioviabilitas yang berbeda. Cu-klorofilin sebagai salah satu 
turunan klorofil mempunyai aktivitas antioksidan yang lebih tinggi dibandingkan klorofil alami (Jumadin dkk., 2017).

Pengembangan produk baru dan diversifikasi olahan dari berbagai tepung dalam menunjang ketahanan pangan selama ini masih terfokus pada sumberdaya tepung yang ada seperti tepung terigu, beras, jagung, dan tapioka (Saragih, 2013). Dengan memanfaatkan daun singkong yang diolah menjadi tepung dapat menambah bahan pangan alternatif yang dapat dijadikan olahan bahan pangan.

\section{Metodologi Penelitian}

Penelitian ini telah dilaksanakan pada bulan Juli 2017 sampai Agustus 2017 dilakukan di Labolatorium Pengolahan dan Pengawasan Mutu Hasil Pertanian, Labolatorium Kimia dan Biokimia Hasil Pertanian dan Laboratorium Agronomi. Jurusan Teknologi Hasil Pertanian Fakultas Pertanian Universitas Mulawarman Samarinda. Bahan yang digunakan untuk pembuatan beras analog adalah tepung Mocaf dan tepung jagung yang diperoleh dari industri di samarinda dan tepung daun singkong adalah daun singkong gajah segar yang diperoleh dari daerah Tenggarong serta bahan-bahan yang digunakan dalam analisis aktivitas antioksidan yaitu alkohol 95\%, aquadest, DPPH serta klorofil. Peralatan yang digunakan dalam penelitian ini terdiri dari peralatan pengolahan untuk membuat beras dari singkong yaitu pisau, baskom, telenan, blender, panci, kompor, gilingan mie, timbangan, gelas takar, serta peralatan yang akan digunakan untuk pengujian sensoris dan analisis aktivitas antioksidan. Rancangan percobaan yang akan digunakan pada penelitian ini dalah Rancangan Acak Lengkap (RAL) faktor tunggal. Penelitian ini menggunakan 5 perlakuan yaitu penambahan tepung daun singkong ke dalam $100 \mathrm{~g}$ campuran tepung Mocaf $80 \mathrm{~g}$ dan tepung jagung $20 \mathrm{~g}$. Masing-masing perlakuan diulang sebanyak 3 kali. Perlakuan yang dilakukan pada penelitian ini adalah sebagai berikut: 0, 2, 4, 6, $8 \mathrm{~g}$ tepung daun singkong. Adapun parameter yang diamati pada penelitian ini yaitu sifat sensoris hedonik dan mutu hedonik serta aktivitas antioksidan pada beras dan nasi analog. Data dari sifat sensoris dianalisis dengan sidik ragam yang seluruh data dikonversi menjadi data interval menggunakan metode MSI (Method of Successive Interval). Untuk perlakuan yang berbeda nyata, maka dilanjutkan dengan Uji Beda Nyata Terkecil (BNT) pada taraf $5 \%$.

Daun singkong yang diolah menjadi tepung adalah tepung dari daun singkong gajah pada bagian daunnya masih muda dari pucuk daun singkong hingga tingkat kebawah. Daun singkong yang telah dipersiapkan disortasi sehingga mendapatkan daun singkong yang baik, kemudian daun singkong dicuci hingga bersih dan ditimbang sebanyak 1 kilogram. Kemudian dikeringkan menggunakan oven pada suhu 55oC selama 16 jam. Selanjutnya dilakukan pengilingan menggunakan blender sampai halus hingga diperoleh tepung daun 
ISSN 2354-7251 (print)

singkong, dan selanjutnya dilakukan pengayakan menggunakan ayakan 80 mesh. Agar mendapatkan tepung yang halus. Tepung Mocaf, tepung jagung, dan konsentrasi penambahan tepung daun singkong disiapkan sesuai dengan perlakuan. Setelah itu tepung Mocaf, tepung jagung dan tepung daun singkong dimasukkan ke dalam wadah yang sama untuk proses pengadukkan air dan tepung daun singkong ditambahkan sesuai dengan perlakuan, serta minyak nabati ditambahkan $10 \%$ aduk adonan hingga kalis selama 5 menit, adonan yang telah siap dilakukkan dengan sistem pengukusan selam 5 menit selanjutnya adonan dicetak menggunakan mesin pencetakkan mie lalu dipotong-potong dengan ukuran kurang lebih menyerupai seperti beras atau panjang $1 \mathrm{~cm}$. Selanjutnya dilakukan pengukusan menggunakan oven pengering 50 oC selama 12 jam akan diperoleh beras analog berbasis tepung Mocaf, tepung jagung dengan penambahan tepung daun singkong disajikan dalam Tabel 1.

Tabel 1. Komposisi Beras Analog Tepung Daun Singkong Dalam 100 gram Bahan

\begin{tabular}{cccc}
\hline Perlakuan & $\begin{array}{c}\text { Tepung Mocaf } \\
\text { (gram) }\end{array}$ & $\begin{array}{c}\text { Tepung Jagung } \\
(\mathrm{gram})\end{array}$ & $\begin{array}{c}\text { Tepung Daun Singkong } \\
\text { (gram) }\end{array}$ \\
\hline $\mathrm{p}_{0}$ & $80 \mathrm{~g}$ & $20 \mathrm{~g}$ & $0 \mathrm{~g}$ \\
$\mathrm{p}_{1}$ & $80 \mathrm{~g}$ & $20 \mathrm{~g}$ & $2 \mathrm{~g}$ \\
$\mathrm{p}_{2}$ & $80 \mathrm{~g}$ & $20 \mathrm{~g}$ & $4 \mathrm{~g}$ \\
$\mathrm{p}_{3}$ & $80 \mathrm{~g}$ & $20 \mathrm{~g}$ & $6 \mathrm{~g}$ \\
$\mathrm{p}_{4}$ & $80 \mathrm{~g}$ & $20 \mathrm{~g}$ & $8 \mathrm{~g}$ \\
\hline
\end{tabular}

\section{Sifat Sensoris (Setyaningsih dkk, 2010)}

Skor skala hedonik yang diberikan untuk atribut warna, aroma, rasa, tekstur, dan rasa adalah 1 = sangat tidak suka, $2=$ tidak suka, $3=$ agak suka, $4=$ suka, $5=$ sangat suka, dengan panelis agak terlatih yang berjumlah 25 orang panelis yang diperoleh dari mahasiswa Teknologi Hasil Pertanian, Universitas Mulawarman. Skor skala hedonik suka dan sangat suka menunjukan bahwa panelis telah menerima produk beras dengan penambahan tepung daun singkong. Untuk penilaian mutu hedonik dari warna meliputi: $5=$ sangat hijau kecoklatan, $4=$ hijau kecoklatan, $3=$ hijau, $2=$ agak hijau $1=$ putih kecoklatan . Untuk penilaian mutu hedonik dari aroma meliputi: $5=$ Sangat beraroma tepung daun singkong, $4=$ beraroma tepung daun singkong, $3=$ agak beraroma tepung daun singkong $2=$ tidak beraroma tepung daun singkong, 1 = sangat tidak beraroma tepung daun singkong, 3). Untuk penilaian mutu hedonik dari tekstur meliputi: $5=$ sangat kenyal, $4=$ kenyal, $3=$ agak kenyal, 2=keras, $1=$ agak keras. Untuk penilaian mutu hedonik dari tekstur meliputi: $5=$ sangat berasa daun singkong, $4=$ berasa daun singkong $3=$ agak berasa daun singkong, $2=$ tidak berasa daun singkong, $1=$ sangat tidak berasa daun singkong.

\section{Uji Analisis Antioksidan Dengan DPPH (Farhan dkk., 2012)}

Uji aktivitas antioksidan dilakukan dengan metode spektrofotometri dengan DPPH (2,2-diphenyl-1-picrylhydrazil). Sebanyak $1 \mathrm{~mL}$ ekstrak yang telah diencerkan dalam etanol ditambahkan ke $1 \mathrm{~mL}$ DPPH (0,15 mm dalam etanol) dan pada saat yang sama, kontrol 
yang terdiri atas DPPH $1 \mathrm{~mL}$ dengan $1 \mathrm{~mL}$ etanol disiapkan. Campuran reaksi dicampur dengan baik lalu diinkubasi dalam keadaan gelap pada suhu ruang selama 30 menit. Absorbansi diukur pada panjang gelombang $600 \mathrm{~nm}$. Klorofil digunakan sebagai kontrol positif dan etanol digunakan sebagai blanko. Kemampuan DPPH ekstrak dihitung dengan menggunakan persamaan berikut:

$\%$ aktivitas antioksidan $=\frac{(\text { Absorbansi kontrol-absorbansi sampel })}{\text { Absorbansi kontrol }} \times 100 \%$

Keterangan :

Absorbansi kontrol adalah absorbansi DPPH + Etanol

Absorbansi sampel adalah absorbansi DPPH radikal + sampel

Uji aktivitas antioksidan dengan DPPH disajikan dalam nilai IC50. Nilai IC50 diperoleh dari persamaan linier persen radikal DPPH terhadap beberapa konsentrasi ekstrak sampel. Persamaan linier yaitu $y=a x+b$.

Adapun metode yang digunakan pada uji klorofil sebagai kontrol positif untuk menghasilkan kurva standar klorofil. Sampel klorofil cair diukur dengan $0,01 \mu$ campur dalam aquadest $10 \mathrm{~mL}$. Pengukuran menggunakan spektrofotometer dengan nilai absorbansi pada panjang gelombang $600 \mathrm{~nm}$.

\section{Hasil dan Pembahasan}

\section{Hedonik dan Mutu Hedonik Warna Nasi Analog}

Nilai uji skala hedonik dan mutu hedonik warna dari nasi analog dengan penambahan tepung daun singkong dapat dilihat pada Gambar 1.

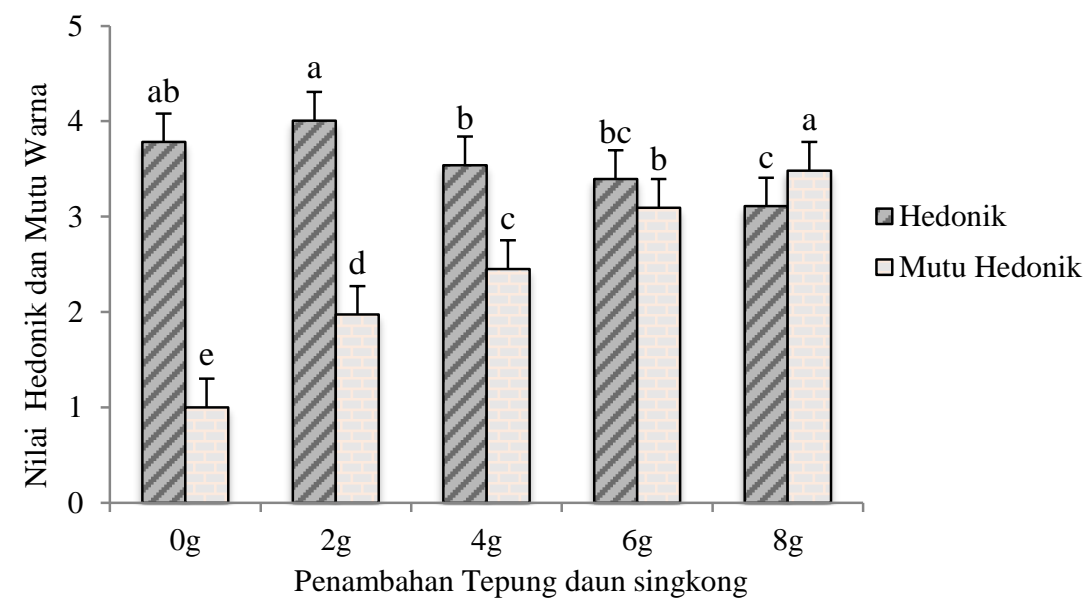

Gambar 1.Pengaruh Formulasi Penambahan Tepung Daun Singkong Terhadap Hedonik Warna Nasi Analog.Keterangan :Angka rata-rata yang diikuti dengan huruf yang sama menunjukkan perbedaan tidak nyata pada taraf $\alpha 5 \%$, Skala Hedonik dan Mutu Hedonik warna 1-5 (sangat tidak suka, tidak suka, agak suka, suka, sangat suka)dan (putih kecoklatan, hijau kecoklatan, agak hijau, hijau, sangat hijau kecoklatan) 
Rata-rata pada mutu hedonik warna nasi analog berkisar antara 1,00 $\pm 0,00$ (sangat tidak berasa daun singkong) sampai 3,48 $\pm 0,03$ (sangat berasa daun singkong). Mutu hedonik warna mengalami peningkatan pada penambahan konsentrasi tepung daun singkong $8 \mathrm{~g}$ dan berpengaruh pada setiap pemberian konsentrasi tepung daun singkong pada masing-masing perlakuan. Semakin tinggi konsentrasi tepung daun singkong, maka semakin tinggi skor penilaian panelis terhadap mutu hedonik warna. Hal ini ditunjukkan dengan rata-rata skor penilaian mutu hedonik panelis untuk warna nasi analog dengan konsentrasi tepung daun singkong $0 \mathrm{~g}$ mempunyai nilai yang paling rendah dengan kriteria putih kecoklatan. Sedangkan skor nilai mutu hedonik dengan konsentrasi tepung daun singkong $8 \mathrm{~g} / 100 \mathrm{~g}$ tepung Mocaf $80 \mathrm{~g}$ : tepung jagung $20 \mathrm{~g}$ mempunyai skor mutu hedonik warna tertinggi dengan kriteria sangat hijau kecoklatan. Pada warna perlakuan dengan $0 \mathrm{~g}$ nasi analog berwarna putih kusam karena tidak ditambahkan dengan tepung daun singkong dan merupakan nasi analog kontrol. Warna yang dihasilkan dari tepung daun singkong dominan hijau sehingga dengan meningkatnya konsentrasi tepung daun singkong yang ditambahkan dalam pembuatan beras analog dapat menyebabkan hasil akhir nasi analog menjadi berwarna hijau. Pada perlakuan tanpa penambahan tepung daun singkong diketahui warna yang dihasilkan putih kusam atau kecoklatan karena tidak ditambahkan dengan tepung daun singkong dan merupakan nasi analog kontrol. Menurut penelitian Yuwono dan Zulfiah (2015) Semakin banyak tepung daun singkong yang ditambahkan maka akan semakin hijau warna yang dihasilkan pada nasi analog dengan penambahan tepung daun singkong. Daun singkong mengandung pigmen berwarna hijau (klorofil) sehingga apabila daun singkong diolah menjadi produk, umumnya produk tersebut berwarna hijau, kecuali proses pembuatannya menggunakan pemanasan dengan suhu tinggi yang akan merusak warna pada daun singkong sehingga warna khas daun singkong akan hilang (Mandriali dkk., 2016).

\section{Hedonik dan Mutu Hedonik Warna Nasi Analog}

Nilai uji skala hedonik dan mutu hedonik warna dari nasi analog dengan penambahan tepung daun singkong dapat dilihat pada Gambar 2. 


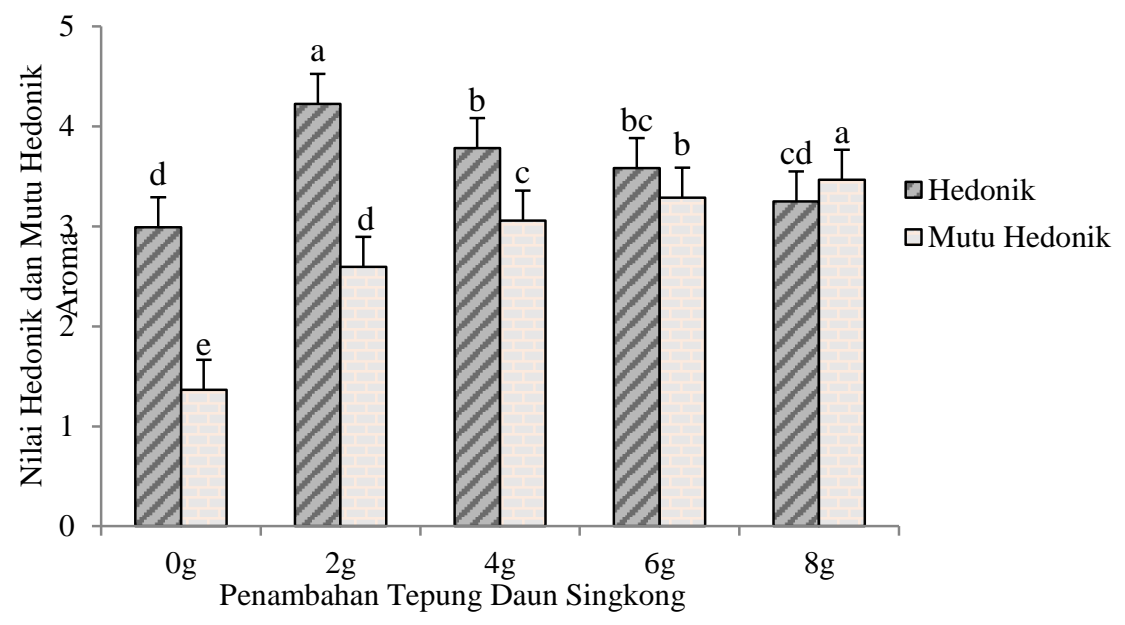

Gambar 2. Pengaruh Formulasi Penambahan Tepung Daun Singkong Hedonik Aroma Nasi Analog. Keterangan : Angka rata-rata yang diikuti dengan huruf yang sama menunjukkan perbedaan tidak nyata pada taraf a 5\%. Skala Hedonik dan Mutu Hedonik warna 1-5 (sangat tidak suka, tidak suka, agak suka, suka, sangat suka)dan (sangat tidak beraroma daun singkong, tidak beraroma daun singkong, agak beraroma daun singkong, beraroma tepung daun singkong, sangat beraroma daun singkong

Rata-rata hasil uji hedonik aroma nasi analog dengan formulasi tepung daun singkong berkisar antara $2,99 \pm 0,30$ sampai dengan $4,22 \pm 0,15$. Perlakuan dengan nilai yang lebih dominan disukai oleh panelis yaitu perlakuan P1 (2 g penambahan tepung daun singkong) yaitu $4,22 \pm 0,15$. Sedangkan nilai terendah yang diberikan panelis terdapat pada perlakuan PO ( $0 \mathrm{~g}$ tanpa penambahan tepung daun singkong pada nasi analog) yaitu $2,99 \pm 0,30$. Sedangkan mutu hedonik aroma mengalami peningkatan pada penambahan konsentrasi tepung daun singkong $8 \mathrm{~g}$ dan berpengaruh pada setiap penambahan konsentrasi tepung daun singkong pada masing-masing perlakuan. Rata-rata hasil uji mutu

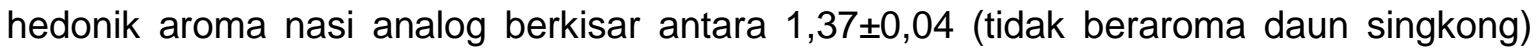
sampai dengan 3,47 $\pm 0,14$ (sangat beraroma tepung daun singkong). Hal ini disebabkan semakin banyak konsentrasi tepung daun singkong yang diberikan maka panelis semakin menerima produk nasi analog yang dihasilkan. Hasil penelitian ini menunjukkan bahwa penambahan tepung daun singkong berpengaruh terhadap aroma nasi analog tepung daun singkong. Semakin banyak penambahan konsentrasi tepung daun singkong maka akan semakin kuat aroma khas daun singkong pada nasi analog yang dihasilkan.

Perlakuan tanpa penambahan tepung daun singkong diketahui aroma yang dihasilkan beraroma tepung Mocaf dan tepung jagung karena tidak ditambahkan tepung daun singkong dan merupakan kontrol. Daun singkong termasuk kelompok sayuran yang mengandung fenol, dimana aroma khas pada daun singkong dihasilkan dari senyawa fenol pada proses pemanasan yang terlalu tinggi akan menyebabkan penurunan kandungan fenolik pada daun singkong, sehingga dapat menurunkan aroma khas daun singkong (Dewi, 2014). Aroma merupakan molekul gas yang dihirup oleh hidung sehingga dapat 
ISSN 2354-7251 (print)

ditentukan bahan pangan tersebut terasa enak saat dikonsumsi (Winarno, 2004). Menurut Wahyuni. 2014, perbedaan pendapat disebabkan setiap panelis memiliki perbedaan penciuman meskipun mereka dapat membedakan aroma namun setiap panelis mempunyai kesukaan yang berlainan.

\section{c. Hedonik dan Mutu Hedonik Rasa Nasi Analog}

Nilai uji skala hedonik dan mutu hedonik rasa dari nasi analog dengan penambahan tepung daun singkong dapat dilihat pada Gambar 3.

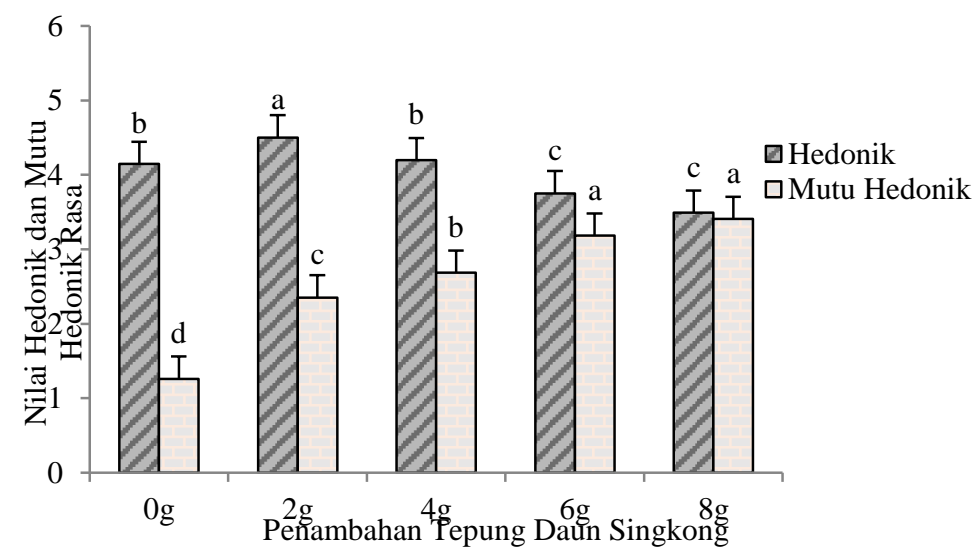

Gambar 3. Pengaruh Formulasi Penambahan Tepung Daun Singkong Terhadap Hedonik Rasa Nasi Analog. Keterangan : Angka rata-rata yang diikuti dengan huruf yang sama menunjukkan perbedaan tidak nyata pada taraf $\alpha 5 \%$. Skala Hedonik dan Mutu Hedonik rasa 1-5 (sangat tidak suka, tidak suka, agak suka, suka, sangat suka) dan (sangat tidak berasa daun singkong, tidak berasa daun singkong, agak berasa daun singkong, berasa daun singkong, sangat berasa daun singkong

Rata-rata hasil uji hedonik rasa nasi analog tepung daun singkong berkisar antara $1,26 \pm 0,07$ (sangat tidak berasa daun singkong) sampai dengan $3,47 \pm 014$ (sangat berasa daun singkong). Hal ini diduga kareana penambahan tepung daun singkong yang dimana semakin besar penambahan konsentrasi tepung daun singkong yang ditambahkan akan semakin kuat rasa daun singkong pada nasi analog yang dihasilkan. Pada perlakuan P0 yaitu $0 \mathrm{~g}$ nasi analog diketahui memiliki rasa yang beda dibanding dengan perlakuan lain yang ditambahkan tepung daun singkong. P0 yaitu tanpa penambahan tepung daun singkong yang merupakan nasi analog kontrol rasa yang dihasilkan hanya rasa tepung seperti tiwul yang tidak berasa daun singkong.

Menurut Suryaningrum dkk. (2002) cita rasa makanan dipengaruhi oleh komponenkomponen yang terdapat di dalam makanan seperti protein, lemak, dan karbohidrat yang menyusunnya. Uji rasa lebih banyak melibatkan indera lidah yang dapat diketahui melalui kelarutan bahan makanan dalam kontak dengan syaraf perasa. Penerimaan panelis terhadap rasa dipengaruhi oleh beberapa faktor, antara lain senyawa kimia, konsentrasi, suhu dan interaksi komponen lain (Winarno, 2004). 


\section{d. Hedonik dan Mutu Hedonik Tekstur Nasi Analog}

Nilai uji skala hedonik dan mutu hedonik warna dari nasi analog dengan penambahan tepung daun singkong dapat dilihat pada Gambar 4.

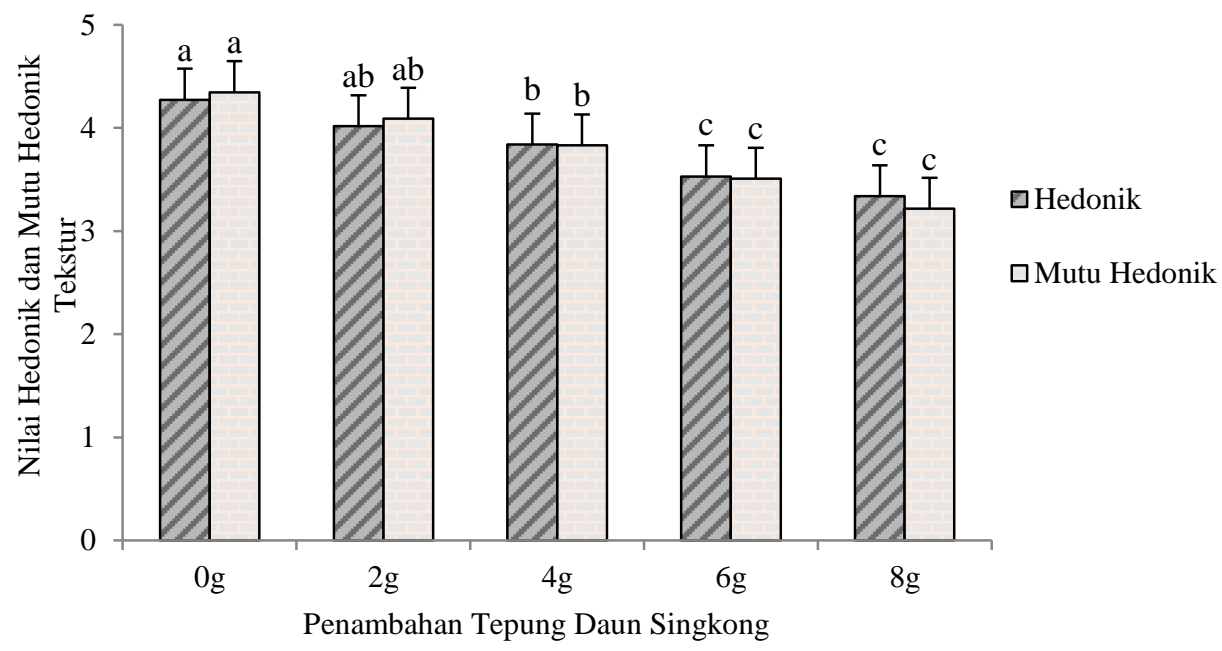

Gambar 4. Pengaruh Formulasi Penambahan Tepung Daun Singkong Terhadap Hedonik Tekstur Nasi Analog. Keterangan : Angka rata-rata yang diikuti dengan huruf yang sama menunjukkan perbedaan tidak nyata pada taraf a 5\%. Skala Hedonik dan Mutu Hedonik rasa 1-5 (sangat tidak suka, tidak suka, agak suka, suka, sangat suka) dan (sangat tidak berasa daun singkong, tidak berasa daun singkong, agak berasa daun singkong, berasa daun singkong, sangat berasa daun singkong

Pada perlakuan $0 \mathrm{~g}$ yaitu tanpa penambahan tepung daun singkong memiliki tekstur yang lebih kenyal dibandingkan perlakuan dengan penambahan tepung daun singkong yang hanya tepung Mocaf dan tepung jagung dalam $100 \mathrm{~g}$ bahan yaitu $80 \mathrm{~g}$ tepung Mocaf dan $20 \mathrm{~g}$ tepung jagung. Kadar amilosa yang tinggi biasanya menghasilkan nasi yang lebih kering dan pera dan merupakan penentu proses pemasakan serta tingkat penerimaan konsumen. Hal ini disebabkan tepung daun singkong tidak memiliki gluten yang berperan terhadap pembentukan tekstur nasi analog yang baik, sedangkan tepung Mocaf dan tepung jagung memiliki kandungan protein gluten (Prasetyo,1988). Semakin banyak penambahan tepung daun singkong pada nasi analog, maka akan semakin kurangnyaa kekenyalan terhadap tekstur nasi analog yang dihasilkan. Oleh karena itu penambahan tepung daun singkong berpengaruh pada tingkatan kekenyalan nasi analog tepung daun singkong. Penelitian yang dilakukan oleh Yuwono dan Zulfiah (2015) menunjukkan bahwa penerimaan panelis terhadap hedonik tekstur dari formulasi beras tiruan berbasis tepung Mocaf dan beras dengan tepung porang yaitu suka. Tekstur merupakan tampilan dalam makanan, kelembutan, bentuk dan keadaan makanan baik kering, basah atau lembab. 


\section{Aktivitas Antioksidan Beras Analog}

Hasil pengujian aktivitas antioksidan beras analog dengan formulasi tepung daun singkong dapat dilihat pada gambar 5

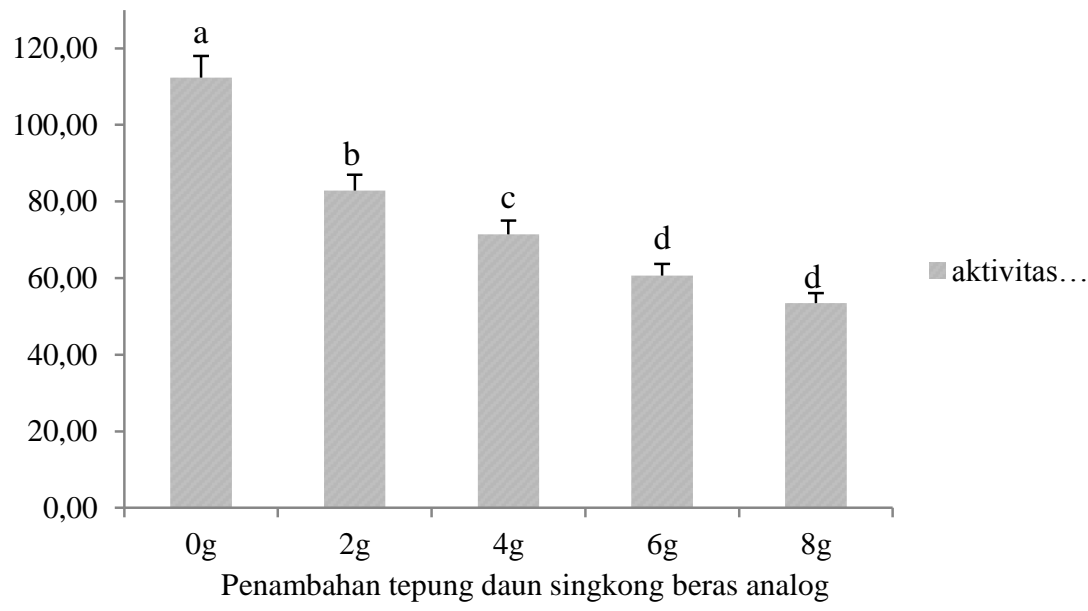

Gambar 5. Pengaruh Penambahan Tepung Daun Singkong Terhadap Aktivitas Antioksidan Beras Analog. Keterangan : Angka rata-rata yang diikuti dengan huruf yang sama menunjukkan perbedaan tidak nyata pada taraf a $5 \%$.

Uji aktivitas antioksidan menggunakan metode DPPH (2,2-difenil-1 pikrilhidrazil), menunjukkan bahwa beras analog dengan formulasi tepung daun singkong nilai IC50 pada absorbansi $600 \mathrm{~nm}$ berkisar 112,370 $\pm 3,52$ sampai dengan 53,424 $\pm 6,69$ hal ini menunjukkan bahwa beras analog tersebut mempunyai aktivitas antioksidan yang relatif kuat. Dari data analisa diketahui bahwa terjadi peningkatan aktivitas antioksidan beras analog tepung daun singkong pada perlakuan penambahan tepung daun singkong sebanyak $2 \mathrm{~g}$ sampai dengan $8 \mathrm{~g}$ yang ditandai dengan menurunnya nilai IC50 pada setiap perlakuan yang dimana menunjukan semakin menurun nilai IC50 maka aktivitas antioksidan semakin tinggi. Namun absorbansi 600 ppm memiliki aktivitas antioksidan relatif kuat.

Andayani dkk., (2008) menyatakan bahwa semakin tinggi konsentrasi ekstrak yang ditambahkan maka semakin tinggi pula aktivitas antioksidannya. Menurut Rohkyani (2015) bahwa metode pemanasan pada produk dapat mempengaruhi nilai nutrisi dan kapasitas antioksidan yang disebabkan oleh keluarnya sejumlah besar komponen antioksidan karena kerusakan dinding sel akibat panas sehingga hal ini juga memungkinkan dapat berpengaruh negatif terhadap penurunan aktivitas antioksidan pada produk. Antioksidan merupakan senyawa yang rentan teroksidasi dengan adanya efek seperti cahaya, panas, logam peroksida atau secara langsung bereaksi dengan oksigen sehingga nilai aktivitas antioksidan mengalami penurunan selama proses pemanasan (Turkmen dkk., 2005).

Hasil penelitian Rachman dkk, (2016) ekstrak metanol dari daun dan umbi tanaman singkong yang diperoleh diukur persentase daya inhibisinya menggunakan metode 
peredaman radikal bebas dengan reagen DPPH (2,2-difenil-1pikrilhidrazil), pada konsentrasi 100 ppm. Hasil pengujian antioksidan menunjukkan bahwa bagian daun singkong jenis Pucuk Biru mempunyai daya inhibisi yang paling tinggi yaitu $88,09 \%$ dan IC50 sebesar 45,16 ppm. Senyawa antioksidan alami yang diduga banyak terdapat dalam sayuran atau dedaunan hijau adalah klorofil. Beberapa hasil penelitian menunjukkan bahwa klorofil dan turunannya memiliki kemampuan sebagai antioksidan dan antimutagenik. Cuklorofilin sebagai salah turunan klorofil mempunyai aktivitas antioksidan yang lebih tinggi dibandingkan klorofil alami (Marquez dkk., 2005). Hasil dari beras analog tepung daun singkong absorbansi $600 \mathrm{~nm}$ dikatakan relatif kuat yang merupakan kisaran penyerapan klorofil. Menurut Kusmita dan Limantara (2009) klorofil mudah mengalami degradasi menjadi turunannya. Turunan klorofil yang berupa feotin tersebut ternyata juga mempunyai banyak manfaat, feotin dapat berfungsi sebagai antioksidan potensial. Secara spesifik bila suatu senyawa dikatakan sebagai antioksidan sebagai antioksidan sangat kuat apabila nilai IC50 kurang dari 50 ppm, antioksidan kuat apabila nilai IC50 antara 50-100 ppm, antioksidan sedang apabila nilai IC50 antara 101-150 ppm dan aktivitas antioksidan lemah apabila nilai IC50 diantara 151-200 ppm (Molyneux, 2004).

\section{$4 \quad$ Kesimpulan}

Perlakuan terbaik berdasarkan uji sensories diperoleh dengan penambahan $2 \mathrm{~g}$ tepung daun singkong. Mutu hedonik warna beras analog dengan warna agak hijau, agak beraroma daun singkong, dengan rasa agak berasa daun singkong, dan dengan tekstur kenyal. Beras analog menggunakan tepung daun singkong dengan konsentrasi $8 \mathrm{~g}$ aktivitas antioksidan paling tinggi dibandingkan perlakuan lainnya. Beras analog yang dihasilkan tergolong mempunyai aktivitas antioksidan dengan kategori relatif kuat nilai IC50 yaitu $53,424 \mathrm{ppm}$.

\section{Daftar Pustaka}

Alsuhendra. (2004). Daya anti-aterosklerosis Zn-Turunan klorofil dari daun singkong (Manihot utilissima) Pada Keilnci Percobaan. Program Pascasarja, Institut Pertanian Bogor, Bogor.

Andayani, R., Maimunah., dan Lisawati, Y. (2008). Penentuan Aktivitas Antioksidan, Kadar Fenolat Total dan Likopen pada Buah Tomat (Solanum lycopersicum L). Sains dan Teknologi Farmasi. 13(1):3-4.

Ariani, Mewa. (2010). Diversifikasi Konsumsi Pangan Pokok Mendukung Swasembada Beras. Prosiding Pekan Serealia Nasional. Balai Pengkajian Teknologi Pertanian Banten. 978-979.

Badan Pusat Statistik. (2016). Perkiraan Penduduk Beberapa Negara, 2000-2014. Jakarta. https://www.bps.go.id. (03 Maret 2017) 
ISSN 2354-7251 (print)

Christianto. (2013). Faktor Yang Memengaruhi Volume Impor Beras Di Indonesia. Jurnal Jibeka, 7(2): 38-43.

Dewi, Lia Kusuma. (2014). Kadar Total Senyawa Fenolik, Flavonoid, Dan Aktivitas Antioksidan Ekstrak Air Dan Ekstrak Metanol Daun Singkong (Manihot esculenta Crantz). Skripsi. Fakultas Matematika dan IImu Pengetahuan Alam. Institut Pertanian Bogor. Bogor.

Farhan. H., Rammal ${ }^{\star}$, H., Hijazi, A., Hamad, H.Daher, A., Reda, M., dan Badran, B. (2012). Invitro antioxidant activity of ethanolic and aqueous extracts from crude malvaparviflora L. grown in Lebanon. Asian Journal of Pharmacential and Clinical Research, 5(3): 234-238.

Hartoyo. (2000). Arah Kebijakan Produksi Beras Untuk Mencapai Ketahanan Pangan Aspek Sosial-Ekonomi/Kesejahteraan Petani. Prosiding Semiloka Penyusunan Kebijakan Perberasan. Bogor: LP-IPB dan Deptan.

Jumadin, L., Satyaningtijas, A., \& Santoso, K. (2017). Ekstrak Daun Singkong Baik Sebagai Antioksidan Pada Burung Puyuh Dewasa Yang Mendapat Paparan Panas Singkat. Jurnal Veteriner. 18(36): 135-143.

Kusmita, L dan Limantara, L. (2009). pengaruh asam kuat dan asam lemah terhadap agregasi dan feofitinisasi klorofil a dan b. Indo J Chem. Universitas Satya Wacana Christian. Malang. 9(1):70-76

Marquez UML, Barros RMC, Sinnecker P. (2005). Antioxidant activity of chlorophylls andtheir derivates. Food Research International. 38(8-9):855-891

Molyneux, P. 2004. The use of the stable free radical 2-diphenylpicryl-hydrazyl (DPPH) for estimating antioxidant activity. Journal Science and Technology. 2(26): 211-219.

Rachman,F, Hartati,S., Sudarmonowati, E. (2016). Aktivitas Antioksidan Daun Dan Umbi Dari Enam Jenis Singkong (Manihot utilissima). Biopropal Industri. 7(2), 47-52.

Rohkyani,I. (2015). Aktivitas Antioksidan Dan Uji Organoleptik Teh Celup Batang dan Bunga Kecombrang Pada Variasi Suhu Pengeringan. Skripsi. Universitas Muhammadiyah Surakarta. Surakarta.

Saragih, B. (2013). Analisis Mutu Tepung Bonggol Pisang dari Berbagai Varietas dan Umur Panen yang Berbeda. Jurnal TIBBS Teknologi Industri Boga dan Busana. 9(1):2229

Setyaningsih, D., Aprianto, A., Sari. M. P. (2010). Analisis Sensori Untuk Produk Pangan dan Agro. IPB Press. Bogor.

Subagio, A., Siti, W., Witono, Y., Fahmi, F. (2008). Prosedur operasi standart produksi mocal berbasis klaster. Southeast Asia Food \& Agricultural Science \& Teknology (SEAFAST). Institut Pertanian Bogor, Bogor.

Suyastiri, M. (2008). Diversifikasi Konsumsi Pangan Pokok Berbasis Potensi Lokal Dalam Mewujudkan Ketahanan Pangan RumahTangga Pedesaan Di Kecamatan Kabupaten Gunung Kidul. Jurnal Ekonomi Pembangunan. 13(1): 51-60

Suryaningrum, D. T., Murdinah., dan Arifin, M. (2002). Penggunaan kappa-karaginan sebagai bahan penstabil pada pembuatan fish meat loaf dariikan tongkol (Euthynnus pelamys. L). Jurnal Penelitian Perikanan Indonesia (Edisi PascaPanen). 8(6)11-13.

Turkmen, N., Sari, F and Velioglu, Y. (2005). The effect of cooking methods on total phenolics and antioxidant activity of selected green vegetables. Journal Food Chemistry. 93(4): 713-718. 
Wahyuni, D dan Widjanarko, S.B. 2015. Pengaruh jenis pelarut dan lama ekstraksi terhadap ekstrak karotenoid labu kuning dengan metode gelombang ultrasonik. Jurnal Pangan dan Agroindustri. 3(2): 390-401.

Wijaya. (2012). Beras Analog Fungsional Dengan Penambahan Ekstrak Teh Untuk Menurunkan Indeks Glikemik Dan Fortifikasi Dengan Folat, Seng, dan lodin. Skripsi. Institut Pertanian Bogor, Bogor.

Winarno, F. G. (2008). Kimia Pangan dan Gizi. M-Brio Press. Jakarta.

Yuwono, S. S., dan Zulfiah, A. A. (2015). Formulasi Beras Analog Berbasis Tepung Mocaf dan Maizena Dengan Penambahan CMC Dan Tepung Ampas Tahu. Jurnal Pangan dan Agroindustri, 3(4): 25-32. 